\title{
"Time for a Change": Loan conditions and bank behavior when firms switch banks
}

\author{
Ioannidou, Vasso ; Ongena, Steven
}

\begin{abstract}
This paper studies loan conditions when firms switch banks. Recent theoretical work on bank-firm relationships motivates our matching models. The dynamic cycle of the loan rate that we uncover is as follows: a loan granted by a new (outside) bank carries a loan rate that is significantly lower than the rates on comparable new loans from the firm's current (inside) banks. The new bank initially decreases the loan rate further but eventually ratchets it up sharply. Other loan conditions follow a similar economically relevant pattern. This bank strategy is consistent with the existence of hold-up costs in bank-firm relationships.
\end{abstract}

DOI: https://doi.org/10.1111/j.1540-6261.2010.01596.x

Posted at the Zurich Open Repository and Archive, University of Zurich ZORA URL: https://doi.org/10.5167/uzh-92703

Journal Article

Accepted Version

Originally published at:

Ioannidou, Vasso; Ongena, Steven (2010). "Time for a Change": Loan conditions and bank behavior when firms switch banks. Journal of Finance, 65(5):1847-1877.

DOI: https://doi.org/10.1111/j.1540-6261.2010.01596.x 
TURNING TO A NEW BANK IS A DEFINING MOMENT for both the firm and its current lenders, and is hence a strategic decision often taken at the highest level. Consequently, a number of recent theoretical models study a firm's decision to switch. Yet, while academics and industry observers point to switching costs as a key source of bank rents, there is surprisingly little empirical evidence on contract conditions just before and after a firm switches to a new bank. An analysis of loan conditions is a first—but essential—step in assessing the role that switching costs play in credit markets. Our paper makes this first step.

We analyze the public credit registry of Bolivia between March 1999 and December 2003. This novel database allows us to follow firms and banks over an extended period of time, to identify switches, and to compare the loan conditions obtained by a switching firm with the terms on loans obtained by a large group of similar nonswitching firms. Given the large number of loans in the database, we analyze only new loans, thereby ensuring the timeliness of the information or loan terms. In order to account for macroeconomic conditions and for differences across lenders, borrowers, contracts, and relationship characteristics, we match on month of loan origination and on bank, firm, contract, and bank-firm relationship characteristics. Using a matching procedure allows us to get closer to answering counterfactual questions such as "What loan rate did the inside bank offer to the switcher?" and "Is this rate higher than the one offered by the outside bank?"

The dynamic pattern of bank loan conditions that arises has not previously been comprehensively documented. Our findings suggest that a new loan granted by an outside bank-one that was not engaged by the firm for at least 1 year and consequently has no recent information about the firm - carries a loan rate that is 89 basis points lower than the rates on comparable new loans from the firm's current inside banks, and 87 basis points lower than the rates on comparable new loans that the outside bank currently extends to its existing customers. We also find that when the firm switches, the outside bank is willing to decrease loan rates by another 36 basis points within the next year and a half. The combined reduction of 122 basis points comprises almost one-tenth of the average observed loan cost of $13.4 \%$.

However, a year and a half after the switch, the new bank starts hiking up the loan rateseven if the firm's condition has not deteriorated. Rates increase slowly at first but eventually at a clip of more than 30 basis points per year. The switcher is thus "back to square one" (i.e., the loan rate charged by the new bank equals what the switcher obtained from its inside bank(s) before switching) after some 3 to 4 years. Not surprisingly, the firm will eventually start looking for more favorable conditions elsewhere. Sooner or later-presumably when it receives a better offer-the firm may again switch banks.

We also observe that firms having weaker relationships with their inside banks (i.e., firms with short or multiple relationships) obtain smaller discounts when they switch. Their loan 
rate cycle is also less pronounced: they receive fewer additional cuts and the rates on their subsequent loans increase at a slower pace. Firms in more concentrated regional banking markets also obtain smaller discounts and experience a shallower loan rate cycle.

Information-sharing through the credit registry helps banks distinguish performing from nonperforming applicants, consistent with theoretical work by Jappelli and Pagano (1993) and Padilla and Pagano (1997, 2000), for example. However, banks still suffer from adverse selection, given that the credit history available to prospective lenders is limited to the 2 months prior to an information request. As a result, some nonperformers make payments for 2 months and manage to switch, but return to nonperformance soon thereafter.

Overall, our findings corroborate key predictions in theoretical models on bank-firm relationships and information-sharing between banks. We document that switching involves lower loan rates that subsequently increase. This pattern is possibly due to informational lockin, as in Sharpe (1990), Rajan (1992), and von Thadden (2004). Over time, banks privately ascertain the firm's quality (by observing its repayment behavior or through the provision of other banking products) and start to charge rates that are higher than the firm's quality warrants. Information asymmetries between new and existing lenders and additional switching costs make such rents possible and prevent firms from instantaneously switching to new lenders. Finding that the loan rate cycle is more pronounced for firms where the hold-up potential is higher provides further support to our interpretation that the uncovered loan rate cycle is due to hold-up problems in bank-firm relationships.

The rest of the paper proceeds as follows. Section I introduces the testable hypotheses and underlying assumptions of banking theory on hold-up problems, and then summarizes the extant empirical literature and shows how our unique data set allows us to improve the test design. Section II describes the data and provides descriptive statistics. Section III tests our hypotheses and provides robustness checks. Section IV concludes. Additional robustness tests as well as evidence consistent with the assumptions underlying hold-up models are provided in an Internet Appendix (available on the Journal of Finance website at http://www.afajof.org/supplements.asp).

\section{Jump to... $\quad$ - \\ I. Hypotheses and Related Literature}

1. Top of page

2. ABSTRACT

3. I. Hypotheses and Related Literature

4. II. Data and Descriptive Statistics

5. III. Results 
6. IV. Conclusion

7. REFERENCES

\section{A. Hold-Up Models: Hypotheses and Assumptions}

A bank's ability to privately and recurrently observe proprietary information about its customer during a relationship can be beneficial to the customer, but it can also impose certain costs. A credit relationship can foster flexibility in writing loan contracts (Boot and Thakor (1994), von Thadden (1995)) and can increase access to capital at a lower cost and/or with less collateral. In addition, banks may smooth interest rates and reschedule capital payments to help their customers overcome financial difficulties (Chemmanur and Fulghieri (1994)). A relationship with a reputable institution may also facilitate current and future funding from both shareholders and alternative outside sources (Diamond (1991)). Finally, the confidentiality of a relationship may facilitate screening and monitoring (Campbell (1979)) and prevent the leakage of proprietary information to product market competitors (Bhattacharya and Chiesa (1995), Yosha (1995)).

Access to private information about a borrower could also lead to hold-up problems, however, and to the extraction of informational rents. In Sharpe (1990), the incumbent bank has the ability to extract rents from its best customers by "holding up" customers from receiving competitive financing elsewhere. 1 The incumbent "inside" bank gains this monopoly power through its informational advantage over the other "outside" banks. If a high quality or "good" borrower tries to switch to a new, uninformed bank, it gets pooled with low quality or "bad" firms and is offered a higher loan rate.

In an amended version of the Sharpe (1990) model, von Thadden (2004) shows that outside banks limit the inside bank's rent extraction by offering competitively lower rates using "optimal randomization" to borrowers that are-at least for them-observationally identical. The equilibrium in von Thadden's (2004) two-period model leads to four testable hypotheses:

- $\quad(\mathrm{H} 1)$

Each period firms may switch banks (i.e., they obtain new loans from new outside banks instead of one of their existing inside lenders).

- $\quad(\mathrm{H} 2)$

Firms that switch receive a loan rate offer from an outside bank that is lower than the offer received from their inside bank.

- $\quad(\mathrm{H} 3)$ 
Over time, the outside bank becomes an insider and extracts rents from good firms.

- $\quad(\mathrm{H} 4)$

Because of adverse selection, a higher proportion of switching firms is worse in terms of unobservable risk characteristics than if the firms had been randomly drawn from the population.

In sum, inside banks charge good borrowers loan rates that are higher than warranted by their true quality (were it publicly known). The more severe the informational asymmetries (e.g., the stronger the bank-firm relationship), the higher the informational rents.

Note that banking models that incorporate hold-up are founded on two key assumptions:

- $\quad(\mathrm{A} 1)$

Relationships mitigate informational asymmetries between firms and banks.

- $\quad(\mathrm{A} 2)$

Relationships create informational asymmetries between inside and outside banks that are alleviated by observable firm information.

\section{B. Empirical Findings in the Literature}

A number of recent papers explore the impact of relationship, firm, bank, and market characteristics on the probability of a firm staying with or switching from/to a bank and the impact of relationship duration on loan rates and other contract terms (Boot (2000), Berger and Udell (2002), and Degryse and Ongena (2008) review this literature).

Ongena and Smith (2001), Farinha and Santos (2002), and Gopalan, Udell, and Yerramilli (2007), for example, study why firms switch to new banks. Ongena and Smith (2001) and Farinha and Santos (2002) find that the likelihood that a firm replaces a relationship increases in duration. The number of bank relationships that the firm maintains also negatively influences the length of a relationship. These studies also find that, ceteris paribus, young, small, high growth, intangible, constrained, or highly leveraged firms switch banks faster.

An important limitation of these studies is the use of annual (or even lower frequency) data. As a result, these investigations cannot focus on what happens right before and after a switch, or they have difficulties in distinguishing switching from nonswitching loans, since data sets are not comprehensive (e.g., loans from an existing borrower could be classified as switching loans because prior or existing loans from a bank cannot be observed). This study, in contrast, 
has access to monthly, comprehensive credit register data that allow us to distinguish between switching and nonswitching loans and to analyze how loan conditions and bank-firm behavior are affected around the time of switching.

An extensive set of papers studies the impact of relationship duration on loan rates. The evidence in these papers is mixed. In their seminal paper, Berger and Udell (1995) find that loan rates decrease in relationship time, which is evidence against hold-up. In contrast, Petersen and Rajan (1994), among others, find that loan rates do not change in relationship time, which may or may not be consistent with hold-up. ${ }^{3}$ Degryse and Van Cayseele (2000), Pozzolo (2004), and Degryse and Ongena (2005), on the other hand, find that loan rates increase in relationship time, consistent with the hold-up hypothesis.

These studies run reduced-form regressions on a cross-section of firms. Over time, however, the composition of the pool of borrowers may change, as banks get to know their customers better and favor certain types. Controls in cross-sectional studies may fail to capture these dynamic effects. Hence, differences in loan rates (or other loan conditions) over relationship time might be biased due to changes in the quality of the pool of borrowers - which could explain the mixed findings in the literature. Moreover, as our results indicate, differences in the average relationship duration and hold-up potential across borrower pools and market conditions may further complicate any comparison and interpretation.

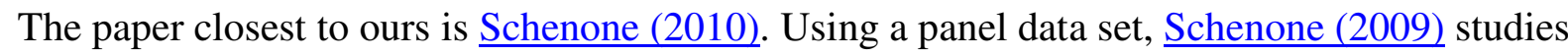
the relationship between loan rates and the intensity of a lending relationship before and after a firm's Initial Public Offering (IPO) — an information-releasing event that should reduce information asymmetries between inside and outside lenders, thereby reducing the scope for hold-up. She finds that prior to an IPO, a firm will pay a lower rate if the lead lender in a syndicate did not participate in any of the firm's prior loans, but that loan rates eventually increase with the proportion of the loans granted by the lead lender, consistent with hold-up. After the IPO, however, no evidence of hold-up is found, as loan rates decrease monotonically with the proportion of loans granted by the lead lender.

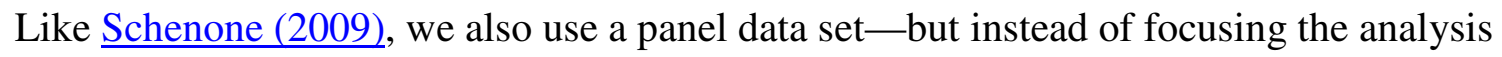
around an information event, we follow firms and banks over an extended period of time, identify switches, and study the loan conditions associated with switching by comparing the loan conditions on switching loans to the conditions on similar nonswitching loans. To identify similar loans, we match on the month of loan origination and on bank, firm, contract, and relationship characteristics. ${ }^{4}$ To examine whether hold-up eventually arises, we follow switchers of unchanged quality and study how conditions on subsequent loans from the new bank develop. $\underline{5}$ 


\section{Jump to...}

\section{Data and Descriptive Statistics}

1. Top of page

2. ABSTRACT

3. I. Hypotheses and Related Literature

4. II. Data and Descriptive Statistics

5. III. Results

6. IV. Conclusion

7. REFERENCES

Our analysis utilizes data from the Bolivian public credit registry, Central de Información de Riesgos Crediticios (CIRC), which is managed by the Superintendent of Banks and Financial Entities (SBEF). The SBEF requires all formal (licensed and regulated) financial institutions to record information on their loans. As a result, this unique database — one of the most comprehensive in the world (Miller (2003)) — contains detailed loan contract information, on a monthly basis, on all outstanding loans granted by all licensed financial institutions in Bolivia. ${ }^{\underline{6}}$ For each loan, we have information on the date of origination, maturity date, contract terms, and ex post performance. For each borrowing firm, we have information on their industry, physical location, legal structure, total bank debt, banking relationships, credit rating, and past repayment history. The registry data, however, cannot be matched with firm balance-sheet data, for example, since for confidentiality purposes the SBEF altered the borrower identities before providing us the data.

The SBEF requires that some of the information in the credit registry be shared among the participating institutions in order to alleviate the otherwise pervasive information asymmetries in the Bolivian credit markets. After written authorization from a prospective customer, a bank can access the registry and obtain a credit report. The report includes information on all outstanding loans of the customer for the previous 2 months. Entries include originating bank, loan amount, loan type, value of collateral, value of overdue payments, and the firm's credit rating from the originating bank. When banks originate new loans they rate each borrower's repayment capacity on a scale from one to five. Ratings equal to one indicate that borrowers are expected to repay their debt in full, while ratings greater than one indicate possible repayment difficulties. After origination, a loan can be downgraded if the borrower's repayment capacity deteriorates.

Because the available information is limited to the previous 2 months, information asymmetries remain..$^{7}$ For example, if a firm pays back an overdue loan, the record resets without any trace of overdue payments on the credit history (Campion (2001)). As we show in 
the Internet Appendix, controlling for other observable characteristics, overdue payments on past loans - even when repayment is eventually made - is a predictor of future repayment problems. Hence, this information (were it made available) could help banks better evaluate new customers.

Apart from the information shared through the registry and the information gathered through a relationship, banks have few other sources of information for their credit evaluations. Most firms do not have audited financial statements-or any statements at all..$^{8}$ As a result, the capital markets are not well developed and the banking sector is the principal source of capital for most firms (Sirtaine, Skamnelos, and Frank (2004)). Since credit derivatives are not widely available, firms seeking to adjust interest payments have to renegotiate or switch.

Our analysis focuses on commercial loans to firms, in particular, on new loan initiations by all commercial banks between March 1999 and December 2003..$^{9}$ All loans are granted by one lender (i.e., are never syndicated). Analyzing only new loans allows us to employ up-to-date and comparable firm and contract information at the precise time that firms "switch" to a new bank. Motivated by models exploring how switching affects the conditions of standard debt contracts, we focus on the initiations of installment and single-payment loans, which comprise $94 \%(66 \%)$ of the total dollar value (number) of loan initiations in our sample and for which the likelihood of repayment is mostly firm-specific and not transaction-specific (as is the case with discount documents). Finally, more than $96 \%$ of these contracts are denominated in US\$. .0

The largest bank operating in Bolivia is Banco Santa Cruz, with around 1.4 billion US\$ in assets, which represents around $20 \%$ of total bank assets in the beginning of the sample period. Five other banks each have assets of more than 0.5 billion US\$. The HerfindahlHirschman Index (HHI) measuring concentration in outstanding bank debt equals 1,335 in the beginning of our sample period and never exceeds 1,587, which suggests moderate market concentration. The HHI for new loans starts at 1,427 and never surpasses 2,334. There is, however, substantial regional variation. In the small regions outside the three large regions (La Paz, Cochabamba, and Santa Cruz, which account for more than 90\% of loan initiations), the HHI varies between 3,000 and 7,000, indicating a high degree of market concentration.

During the sample period there were 33,084 loan initiations of installment and single-payment loans to 2,805 firms (of which 59\% are corporations and $37 \%$ are partnerships or sole proprietorships). The corporations in our sample are much larger than the partnerships or sole proprietorships. At sample entry, the average (median) corporation has $\$ 600,000(\$ 80,000)$ in bank debt outstanding, while the average (median) partnership or sole proprietorship has only $\$ 290,000(\$ 50,000) .^{11}$ Nearly $25 \%$ of the firms in our sample are in the retail trade industry, $18 \%$ are manufacturing firms, and $11 \%$ are real estate firms. The manufacturing firms are the 
largest firms in our sample. Overall, these characteristics are very similar to those reported in Petersen and Rajan (1994) using the U.S. Survey of Small Business Finances (SSBF).

Only $20 \%$ of our sample firms have multiple relationships, and there is a positive correlation between firm size and the number of relationships. The median firm with multiple relationships is in the top $15 \%$ of bank debt outstanding. This pattern is consistent with findings from other countries..$^{12}$ Finally, the incidence of collateral in our sample is only $24 \%$, which is substantially lower than in other samples from more developed economies. For example, in the SSBF sample used by Berger and Udell (1995), the incidence of collateral is $53 \%$. Difficulties in seizing and liquidating pledged assets due to judicial inefficiencies and weak creditor rights, for example, could explain the low incidence of collateral in our sample. ${ }^{13}$

Jump to...

\section{Results}

1. Top of page

2. ABSTRACT

3. I. Hypotheses and Related Literature

4. II. Data and Descriptive Statistics

5. III. Results

6. IV. Conclusion

7. REFERENCES

We now test the four model hypotheses. We first document that switching occurs (H1), then analyze the loan rates at which firms switch $(\mathrm{H} 2)$, investigate how loan rates develop over relationship time (H3), and finally investigate adverse selection by comparing the loan repayment performance of switchers and nonswitchers both before and after the switch $(\mathrm{H} 4)$.

\section{A. Switching A.1. Definitions}

We define a new loan as a switch (or a switching loan) when a firm obtains a new loan from a bank with which it did not have a lending relationship during the prior 12 months. We call such banks outside banks. In effect, we conservatively assume that key inside information can get stale as quickly as within 1 year. We call inside banks those banks with a lending relationship with the firm during the prior 12 months. We label any new loan that the inside bank grants to its existing customers as a nonswitching loan. Figure 1 illustrates our definitions. Next, we discuss some key features of our definitions. 


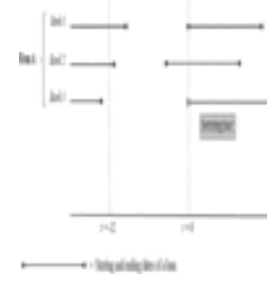

Figure 1. Switchers, inside banks, and outside banks. The figure depicts the definition of switchers, inside banks, and outside banks. We call firm A the switcher and bank 3 the outside bank for firm A, as bank 3 lent to firms $\mathrm{X}, \mathrm{Y}$, and $\mathrm{Z}$ but not to firm A during the last 12 months. Banks 1 and 2 are the switcher's inside banks, as in the last 12 months firm A had at least one loan outstanding with these banks.

\section{Download figure to PowerPoint}

Our choice of 12 months is motivated by empirical findings suggesting that a substantial portion of the bank's inside information is collected during the first year (Cole (1998)). In the Internet Appendix, we show that our main results are robust to using 24- and 36-month cutoffs. A lending relationship encompasses any form of used or unused credit (including credit cards, credit lines, overdrafts, and discount documents). As we aim to compare the loan conditions from the outside bank with those of the inside bank, we do not retain or analyze the few firms that did not obtain any bank credit during the previous 12 months.

Our definition of switching does not differentiate between those firms that "move" between banks and those firms that "add" a bank relationship. ${ }^{14}$ We believe that investigating the conditions under which a firm obtains a loan from another bank (and not from an existing lender) is the most pertinent question - and it is the one addressed in von Thadden (2004). Differentiating between "adders" and "movers" based on whether they have or do not have other outstanding loans at the time of the switch does not necessarily provide a meaningful distinction. Adders could be classified as movers if, at the time of the switch, their inside loans expired and were not renewed until after they got a loan from an outside bank. Similarly, movers could be classified as adders if their inside loans happened to expire a few months after the switch. It is therefore hard to develop a meaningful classification without relying on future (but possibly endogenous) information. That is, firms may decide to reverse their initial decisions, depending on future offers they receive from both the inside and outside banks.

\section{A.2. Statistics}

Given our definition of switching, the data set yields 1,062 switching loans granted to 615 firms, among the 33,084 loan initiations of installment and single-payment loans (H1). This 
implies that $3 \%$ of the loan originations are switching loans, and that $22 \%$ of the 2,805 firms in our sample switch banks at some point during our 5-year sample period (i.e., $4.5 \%$ per year). These percentages are comparable to those in Farinha and Santos (2002), for example, who document that $64 \%$ of the 1,577 Portuguese newly created firms in their sample similarly switch during the 16-year sample period they study (i.e., $4 \%$ per year; see Degryse, Kim, and Ongena (2009) for a general overview of the evidence on relationship duration).

With regard to the switchers, $77 \%$ are corporations and $20 \%$ are partnerships or sole proprietorships, suggesting that corporations are more prone (or able) to switch. However, even after conditioning on legal structure, switchers are larger than the other firms in our sample. The average (median) corporation that switches has $\$ 1,087,090(\$ 153,000)$ in bank debt—almost double the amount of nonswitching corporations. Similarly, switching partnerships or sole proprietorships have $\$ 753,227$ (\$150,000) in bank debt-almost triple the amount of nonswitching partnerships and sole proprietorships. On the other hand, the distribution of switchers across industries is very similar to the overall sample: $27 \%$ of the switchers are in retail trade, $21 \%$ in manufacturing, and $11 \%$ in real estate. Approximately $64 \%$ of the switchers have a single bank lending relationship, as opposed to $79 \%$ for the overall sample, consistent with the hypothesis that switchers are larger firms. In fact, firms that switched more than once during the sample period are even larger. Among the 615 firms, $64 \%$ switched only once, $20 \%$ switched twice, and $16 \%$ switched more than two times.

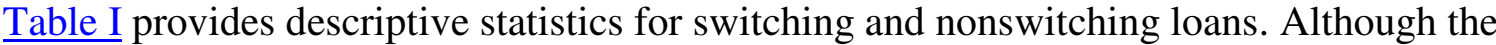
loan rates on switching loans are 28 basis points lower than rates on nonswitching loans, there are other differences between the two groups that could explain the lower rates. For example, switching loans are more likely (than nonswitching loans) to have shorter maturities, to be collateralized, to have installments instead of a single payment at maturity, and to be given to firms with better ratings. These differences suggest that outside banks, being aware of their informational disadvantage, might try to reduce this disadvantage by adjusting the various contract terms and the types of firms to which they are willing to lend. Hence, controlling for loan and firm characteristics is essential in estimating the loan rate at which firms are willing to switch. The matching procedure we follow is geared to meet this challenge.

\section{Table I. Selected Characteristics of Switching Loans and Nonswitching Loans}

Switching Loans $(n=1,062)$

\begin{tabular}{cccccc}
\hline Mean & $\begin{array}{c}\text { St. } \\
\text { Dev. }\end{array}$ & Median & Mean & $\begin{array}{c}\text { St. } \\
\text { Dev. }\end{array}$ & $\begin{array}{c}\text { Media } \\
n\end{array}$ \\
\hline
\end{tabular}


Table I. Selected Characteristics of Switching Loans and Nonswitching Loans

$$
\text { Switching Loans }(n=1,062)
$$

Nonswitching Loans $(n=$ 32,022)

1. ${ }^{a}$

We report the mean, standard deviation, and median for selected loan and firm characteristics. The unit of observation in this table is the number $(n)$ of loan initiations for switching and nonswitching loans, respectively. The summary statistics for Proportion of Loan Collateralized are calculated for the subsample of loans that are collateralized. We assess the differences in means using the Student's $t$-test. We assess the differences in medians using the Wilcoxon-MannWhitney test for continuous variables and the Pearson's Chi-square test for categorical variables. We indicate whether the differences between the corresponding mean and median values are significant at the $10 \%$, $5 \%$, and $1 \%$ levels using *,**, and $* * *$, respectively.

Loan rate (in basis points) $1,328 * * * \quad 396$ $1,370 * * * \quad 1,356$ 301 1,400

Installment loans (in \%)

$$
56.03 * * *
$$

49.66

$100 * * *$

46.74

49.89

0

Loans

denominated

$96.23 * * *$

19.05

$100^{*}$

98.02

13.94

100

in US\$ (in\%)

Credit rating

$1.04 * * *$

0.27

$1 * * *$

1.17

0.51

Sole

\begin{tabular}{lcccccc}
$\begin{array}{l}\text { proprietorshi } \\
\text { ps (in\%) }\end{array}$ & $4.90 * * *$ & 21.59 & $0 * * *$ & 12.83 & 33.44 & 0 \\
$\begin{array}{l}\text { Partnerships } \\
\text { (in\%) }\end{array}$ & $11.68 * * *$ & 32.13 & $0 * *$ & 14.35 & 35.06 & 0 \\
$\begin{array}{l}\text { Corporations } \\
\text { (in\%) }\end{array}$ & $80.60 * * *$ & 39.56 & $100 * * *$ & 70.75 & 45.49 & 100 \\
\hline
\end{tabular}


Table I. Selected Characteristics of Switching Loans and Nonswitching Loans

\begin{tabular}{cccccc}
\multicolumn{2}{c}{ Switching Loans $(n=1,062)$} & \multicolumn{3}{c}{ Nonswitching Loans $(n=$} \\
32,022) \\
Mean & $\begin{array}{c}\text { St. } \\
\text { Dev. }\end{array}$ & Median & Mean & $\begin{array}{c}\text { St. } \\
\text { Dev. }\end{array}$ & $\begin{array}{c}\text { Media } \\
\text { n }\end{array}$
\end{tabular}

Collateralize

d loans

$40.67 * * * \quad 49.14$

0

23.27

42.25

0

(in\%)

Proportion

of loan

collateralize

$193.11 \quad 251.89$

123.52

611.75

$6,929.7$

129.91

d (in\%)

Loan

maturity (in $\quad 11.20 * * * \quad 17.67 \quad 5.98 * * * \quad 18.20 \quad 25.84 \quad 5.90$

months)

Loan amount

$331,329 *$

$825,60 \quad 80,000 * *$

(in US\$)

**

0

155,670

$\begin{array}{cc}439,58 & 41,000 \\ 6 & \end{array}$

Floating loan

rate (in\%)

$7.81 * * *$

26.85

$0 * * *$

5.34

22.4

0

Total bank

debt (in

$\begin{array}{cc}1,918,439 & 123,03 \\ 8\end{array}$

434,302

$1,983,91$
8

472,43

US\$)

Multiple

bank

relationships

$82.39 * * *$

38.11

$100 * * *$

54.00

49.84

100

(in\%)

Primary

lender (in\%)

$40.30 * * *$

49.07

$0 * * *$

72.75

44.52

Scope of

bank

relationship

$3.11 * * *$

17.36

0

27.60

44.70

(in\%) 


\section{B. Loan Rates for Switchers \\ B.1. Matching}

We now examine whether the loan rate that the switcher receives from the outside bank is lower than the rate its inside bank offered (H2). Since the inside bank's unsuccessful offer is unobservable, we approximate it using similar loans that the inside bank granted in the same month to other comparable firms (Figure 2). Recognizing the possible impact of bank characteristics on the inside and outside offers, in a similar matching exercise we also compare the rates on the switching loans to the rates of similar loans that the switcher's outside bank granted in the same month to other comparable existing customers (Figure 3 ).

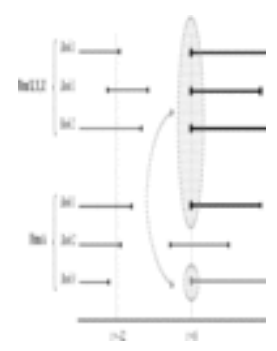

Figure 2. Switching versus nonswitching loans at the switcher's inside bank. The figure displays the analysis in Tables III (Column I) and $\underline{\mathrm{V}}$, where we compare the rate and other conditions of the switching loan with comparable new loans from the switcher's inside banks at the time of the switch.

$\underline{\text { Download figure to PowerPoint }}$

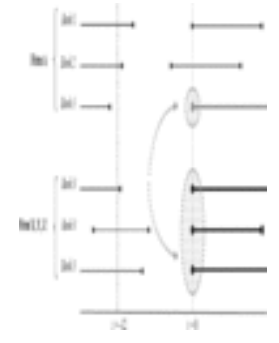

Figure 3. Switching versus nonswitching loans at the switcher's outside bank. The figure displays the analysis in Table III (Column II), where we compare the rate of the switching loan with the rate of comparable nonswitching loans that the switcher's outside bank originates at the time of the switch.

\section{$\underline{\text { Download figure to PowerPoint }}$}

Table II provides a description of the variables we match on. $\frac{15}{}$ Apart from matching on the month of loan origination and the identity of the switcher's inside or outside bank, we also match on currency denomination and loan type-as well as publicly observable firm 
characteristics such as credit rating, region, industry, and legal structure. We also match on other contract terms such as the degree of collateralization, maturity, amount, and loan rate proviso (i.e., floating or fixed rate) in order to make the two groups of loans as comparable as possible.

Table II. Matching Variables

$\begin{array}{lll}\text { Category } & \begin{array}{l}\text { Matching } \\ \text { Variables }\end{array} \quad \text { Possible Values }\end{array}$

1. ${ }^{a}$

We report the number of possible values (\#) and a range (or list) of values for the matching variables.

\begin{tabular}{|c|c|c|c|}
\hline Macro & Year: month & 58 & 1999:03 - 2003:12. \\
\hline Bank & Inside bank & 2 & $\begin{array}{l}=1 \text { if the firm had a lending relationship } \\
\text { with the bank in the last } 12 \text { months, and = } \\
0 \text { otherwise. }\end{array}$ \\
\hline Bank & Outside bank & 2 & $\begin{array}{l}=1 \text { if the firm did not have a lending } \\
\text { relationship with the bank in the last } 12 \\
\text { months, and }=0 \text { otherwise. }\end{array}$ \\
\hline Loan & $\begin{array}{l}\text { Currency } \\
\text { denomination }\end{array}$ & 2 & $=1$ if Bolivian pesos, $=0$ if US dollars. \\
\hline Loan & Loan type & 2 & $\begin{array}{l}=1 \text { if single-payment loan, }=0 \text { if } \\
\text { installment loan. }\end{array}$ \\
\hline Firm & Credit rating & 5 & $\begin{array}{l}\text { No problems }(=1) \text {, potential problems, } \\
\text { unsatisfactory, doubtful, write-off }(=5) \text {. }\end{array}$ \\
\hline Loan & Region & 13 & $\begin{array}{l}\text { Chuquisaca, La Paz, Cochabamba, Oruro, } \\
\text { Potosi, Tarija, Santa Cruz, Beni, Pando, } \\
\text { USA, Argentina, Paraguay, Panama. }\end{array}$ \\
\hline Firm & Industry & 18 & $\begin{array}{l}\text { Agriculture and cattle farming; Forestry } \\
\text { and fishery; Extraction of oil and gas; } \\
\text { Minerals; Manufacturing; Electricity, gas, } \\
\text { and water; Construction; Wholesale and } \\
\text { retail trade; Hotels and restaurants; } \\
\text { Transport, storage, and communications; }\end{array}$ \\
\hline
\end{tabular}


Table II. Matching Variables

$\begin{array}{lll}\text { Category } & \begin{array}{l}\text { Matching } \\ \text { Variables }\end{array} \quad \text { Possible Values }\end{array}$

Financial intermediation; Real estate activities; Public administration, defense, and compulsory social security;

Education; Communal and personal social services; Activities of households as employees of domestic personnel; Activities of extraterritorial organizations and bodies; Other activities.

Sole proprietorships; Partnerships (i.e., all or some partners have unlimited liability);

Firm Legal structure 4 Corporations (i.e., all partners have limited liability); Other (includes public companies, municipalities, social, cultural, sport, and religious associations).

$=1$ if the matched loans have similar ratios of collateral value to loan size, and

Proportion of $=0$ otherwise. Collateral value is the

Loan loan collateralized

2 estimated market value of the collateralized assets at the time of the loan origination. To define similar ratios we use a window of $(-30 \%,+30 \%)$.

$=1$ if the matched loans have similar

Loan Loan maturity 2 maturity (using a $(-30 \%,+30 \%)$ window), and $=0$ otherwise.

$=1$ if the matched loans have similar

Loan Loan amount

Loan

Floating loan rate

2 contract amount (using a $(-30 \%,+30 \%)$ window), and $=0$ otherwise.

$=1$ if the interest rate on the loan varies

2 more than $50 \%$ of the time, and $=0$ otherwise.

Firm

Prior credit

$=1$ if the matched nonswitchers have the rating from same rating as the switchers' most recent 
Table II. Matching Variables

\section{Category $\quad$ Matching}

inside banks

Loan rate on

Loan prior inside

loans

Firm

$\begin{array}{ll}\text { Relation } & \text { Relationship } \\ \text { length }\end{array}$

Firm

Relation Primary lender

Scope of the

$\begin{array}{ll}\text { Relation } & \text { bank } \\ & \text { relationship }\end{array}$

\section{Possible Values}

inside rating that existed prior to the switch (when there are multiple ratings we use the worse rating), and $=0$ otherwise.

$=1$ if the matched inside loans have similar loan rates (using a $(-30 \%,+30 \%)$ window) as the switcher's most recent inside loan prior to the switch (if there are multiple loans, we use the loan with the highest loan rate), and $=0$ otherwise.

$=1$ if the firms of the matched loans have 2 similar total bank debt (using a ( $-30 \%$, $+30 \%$ ) window), and $=0$ otherwise.

The length of a bank-firm relationship in months.

$2=1$ if the firm has outstanding loans with more than one bank, and $=0$ otherwise.

$=1$ if the value of loans from a bank is at

2 least $50 \%$ of the firm's loans, and $=0$ otherwise.

$=1$ if the firm has additional products (i.e., credit card used or not used, 2 overdraft used or not used, and discount documents) with a bank, and $=0$ otherwise.

If banks observe more about the borrowers than we do, and choose contract terms on the basis of these unobservable-to-us characteristics, then matching on the above contract terms should also reduce unobserved borrower heterogeneity. Unobserved borrower heterogeneity works against finding evidence consistent with H2. In von Thadden (2004), unobservable bad borrowers are more likely to switch. Hence, if our matching variables do not adequately capture borrower quality, then bad switchers are more likely to be paired with good (instead 
of bad) nonswitchers, resulting in smaller estimated cuts (see simulations of the von Thadden model in the Internet Appendix). To further reduce any possible unobserved borrower heterogeneity, and to control for possible rating biases, in the sensitivity analysis we also match using the switcher's most recent inside rating or loan rate prior to the switch. ${ }^{16}$ Notice that matching on both the month of loan origination and loan maturity also allows us to control for unobservable economic conditions that could affect the loan rates.

Overall, our testing strategy has three steps: (i) we match each switching loan with all similar new nonswitching loans to other comparable firms granted by the switcher's inside or outside banks at the time of the switch; (ii) we calculate the spreads between the rates on the switching loans and each matched loan, $r_{\text {Switch }}-r_{\text {Not-switch }}$, and (iii) we regress the spreads on a constant (i.e., we estimate $r_{\text {Switch }}-r_{\text {Not-switch }}=\alpha+\zeta$, where $\alpha$ is the constant term and $\zeta$ is the error term). A negative and statistically significant constant term suggests that the rates on switching loans are on average lower than the rates on comparable nonswitching loans, which we interpret as evidence consistent with $\mathrm{H} 2$ and estimates of switching costs. ${ }^{17}$

\section{B.2. Switching Loans Matched with Loans from Inside or Outside Banks}

B.2.1. Main Results Table III presents the matching variables, the number of observations, the coefficient on the constant in this regression, robust standard errors, and the resulting significance level (at which the null hypothesis that the coefficient equals zero can be rejected).

Table III. Spreads between Interest Rates on Switching Loans and Matched Loans Given by Inside or Outside Banks

Matching Variables I II III IV

1. ${ }^{a}$

We assess the spread between the interest rate on a switching loan and the interest rates on new loans obtained (by other firms) from the switchers' set of inside banks in Column I and from the switcher's outside bank in Columns II to V. We match on the indicated variables. All variables are defined in Table II. The variables in Column V refer to the strength of the switchers' relationships with the inside banks prior to the switch. We regress the spreads on a constant and report the coefficient on the constant. We weight each observation by one over the total number of comparable nonswitching loans per switching loan. 
Table III. Spreads between Interest Rates on Switching Loans and Matched Loans Given by Inside or Outside Banks

Matching

Variables

I II

III

IV

$\mathbf{V}$

We cluster at the switching-firm level and report robust standard errors between parentheses. We also report the difference between the mean interest rate on the switching loans and the mean interest rate on the nonswitching loans in each column. We report standard errors between parentheses. $*, * *$, and $* * *$ indicate significance at the $10 \%, 5 \%$, and $1 \%$ levels, two-tailed.

Year:

month

Yes

Yes

Yes

Yes

Yes

Set of

inside

Yes

banks

Bank

Yes

Yes

Yes

Yes

Currency

denominati

Yes

Yes

Yes

Yes

Yes

on

Loan type

Yes

Yes

Yes

Yes

Yes

Credit

rating

Yes

Yes

Region

Yes

Yes

Yes

Yes

Yes

Economic

activity

Yes

Yes

Yes

Yes

Yes

Legal

structure

Yes

Yes

Yes

Yes

Yes

Proportion

of loan

collateralize

Yes

Yes

Yes

Yes

Yes

d

Loan

Yes

Yes

Yes

Yes

Yes 
Table III. Spreads between Interest Rates on Switching Loans and Matched Loans Given by Inside or Outside Banks

\begin{tabular}{|c|c|c|c|c|c|}
\hline $\begin{array}{l}\text { Matching } \\
\text { Variables } \\
\text { maturity }\end{array}$ & I & II & III & IV & $\mathbf{V}$ \\
\hline $\begin{array}{l}\text { Loan } \\
\text { amount }\end{array}$ & Yes & Yes & Yes & Yes & Yes \\
\hline $\begin{array}{l}\text { Floating } \\
\text { loan rate }\end{array}$ & Yes & Yes & Yes & Yes & Yes \\
\hline $\begin{array}{l}\text { Prior credit } \\
\text { rating from } \\
\text { inside } \\
\text { banks }\end{array}$ & & & Yes & & \\
\hline $\begin{array}{l}\text { Loan rate } \\
\text { on prior } \\
\text { inside loans }\end{array}$ & & & & Yes & \\
\hline $\begin{array}{l}\text { Prior } \\
\text { relationship } \\
\text { length }\end{array}$ & & & & & Yes \\
\hline $\begin{array}{l}\text { Prior } \\
\text { multiple } \\
\text { bank } \\
\text { relationship } \\
\text { s }\end{array}$ & & & & & Yes \\
\hline $\begin{array}{l}\text { Prior } \\
\text { primary } \\
\text { lender }\end{array}$ & & & & & Yes \\
\hline $\begin{array}{l}\text { Prior scope } \\
\text { of the bank } \\
\text { relationship }\end{array}$ & & & & & Yes \\
\hline $\begin{array}{l}\text { Number of } \\
\text { switching } \\
\text { loans }\end{array}$ & 304 & 276 & 233 & 82 & 45 \\
\hline
\end{tabular}




\section{Table III. Spreads between Interest Rates on Switching Loans and Matched Loans Given by Inside or Outside Banks}

Matching

Variables

Number of

nonswitchin

967

g loans

Number of

observation

$\mathrm{s}$ (matched

pairs)

Spread in

basis points

with

matching

Spread in

basis points

without

matching

I

$*$
II

609

487

131

64

III

IV

V

659

159

95

1,178

820

$-86.9$

$-96.8$

$-82.2$

$-97.2$

$(19.2)^{* *}$

$(17.5)^{* *}$

$*$

$(19.7)^{* *}$

$*$

$(25.0)^{* *}$

*

(44.3)*

*

$-35.9$

$-56.7$

19.83

(32.1)

(62.8)

(81.10)

We start by comparing the switching loan to comparable nonswitching loans from the switcher's inside banks. Figure 2 depicts our comparison. Matching on the first 12 variables listed in Column I of Table III, we are left with 304 switching loans that are in 1,178 matched pairs with 967 nonswitching loans. Every switching loan is therefore matched with on average 3.9 "comparable" nonswitching loans, that is every switching loan is repeated on average 3.9 times. To account for this multiplicity, we cluster the standard errors at the switching firm level and adjust the point estimates by weighting each observation by one over the total number of comparable nonswitching loans per switching loan. ${ }^{18}$

The coefficient on the constant in the regression indicates that loan rates on the switching loans are 89 basis points below the rates on comparable new loans from the inside banks. To separate the effect of matching from the effect of changes in the sample (due to changes in the matching criteria in subsequent specifications), we also calculate in each column the difference between the mean interest rate on the switching loans and the mean interest rate on the nonswitching loans. This "unmatched" difference equals -77 basis points, and is 12 basis points larger than the "matched" spread of -89 basis points. Hence, as mentioned earlier, 
ignoring heterogeneity (in this case, by not matching at all) works against finding evidence consistent with $\mathrm{H} 2 .{ }^{19}$

A drop of 89 basis points in the loan rate is not trivial: the average loan rate during the sample period is $13.56 \%$ (or 1,356 basis points), with a standard deviation of 305 basis points, and the average bank spread (i.e., the difference between ex ante loan rates and deposit rates) is 966 basis points, with a standard deviation of 145 basis points. Overall, our findings in Column I suggest that switchers can obtain a substantially lower loan rate at their new bank than an an of their current inside lenders, consistent with $\mathrm{H} 2$.

Next, instead of matching using the loans of the inside banks, we match using the loans of the outside banks to their existing customers. Figure 3 depicts our comparison. Since the comparison is now within the same bank during the same month, the loan rate differences between switching and nonswitching loans cannot be attributed simply to differences in the marginal cost of funds between inside and outside banks (or more generally to any form of unobserved heterogeneity with respect to the two banks). This is an important advantage over the matching exercise in Column I or an alternative exercise whereby some bank characteristics are added to the set of matching variables. We therefore consider Column II as our benchmark model. The estimated spread is equal to -87 basis points, which is very similar to Column I. ${ }^{20}$ However, ignoring matching in this case leads to a substantially larger bias in the estimated spreads. ${ }^{21}$

Overall, the results in Columns I and II suggest that the outside banks are not different from the switcher's current inside banks in their pricing behavior vis-à-vis their existing customers. These findings also suggest that switching might give a firm an initial advantage that fades over time-as other comparable customers of the outside banks have to pay more (i.e., if the rate cut were permanent, we would have found no systematic differences in the loan rates between similar new and existing customers). In other words, our findings suggest that after winning the firm with an attractive offer, the outside bank starts behaving like an inside bank, extracting rents from good firms, consistent with H3. To test this hypothesis more directly, we investigate the dynamic path of loan rates (in Section IV.C) by tracing switchers of unchanged quality over time in their new bank. But first we subject our benchmark model to additional robustness exercises and explore alternative explanations for hold-up.

B.2.2. Robustness Analysis We start by replacing the credit rating that the switchers obtain from their new bank with the most recent rating they obtained from their inside bank prior to the switch. The inside bank's ratings might be more informative, since the inside bank may know the firm better. Results presented in the Internet Appendix suggest that ratings become better predictors of ex post performance as the length of a relationship increases, consistent with A1. $\stackrel{22}{ }$ Moreover, matching on the inside bank's rating (i.e., requiring the comparable 
matched firms to have the same inside rating as the switcher) could help better approximate the inside bank's unobserved offer to the switcher. Matching on the inside bank's ratings in Column III leaves 659 observations and results in an average spread of -97 basis points.

In Column IV we also replace the inside bank's most recent credit rating with the most recent loan rate. Matching on loan rates instead of ratings has some potential advantages. Ratings are observable by other banks through the credit registry, and affect banks' loan loss provisioning (i.e., banks have to provision more for loans with worse ratings). If banks are concerned about free-riding behavior by other banks or the costs of assigning low ratings, then credit ratings might be less informative than loan rates (which are not directly observable by other banks and do not determine loan loss provisioning). Matching on the loan rate yields a spread of -82 basis points (although the number of observations and loans drops to 159 and 82, respectively). ${ }^{23}$

Matching on the loan rate should also control for the effect of the strength of switchers' relationships with their inside banks (i.e., switchers with strong relationships with their inside banks are more exposed to hold-up and thus receive worse inside offers). Nevertheless, in Column V, we also match directly on the strength of switchers' relationships with their inside banks prior to the switch (i.e., we require that the strength of switchers' relationships with their inside banks prior to the switch be similar to the relationship strength of the matched nonswitchers).

To capture relationship strength we use four indicators: Prior Relationship Length (= average length of prior relationships), Prior Multiple Bank Relationships (= 1 if prior to the switch the firm has outstanding loans with more than one lender, and $=0$ otherwise), Prior Primary Lender (= 1 if prior to the switch at least one of the firm's inside banks is a Primary Lender, and = 0 otherwise), and Scope of Prior Bank Relationships (= 1 if prior to the switch the firm has additional products from at least one inside bank, and $=0$ otherwise). Matching on these four characteristics reduces the number of observations to 95, but leaves the spread similar to previous estimates at -97 basis points, which suggests that other variables were already sufficiently capturing the effect of relationship strength on the inside banks' unobserved offers.

B.2.3. Hold-Up and Alternative Explanations If the estimated loan rate discounts can be attributed to hold-up problems (as hypothesized above), then we should also observe that firms with stronger relationships with their inside banks prior to the switch (i.e., firms with greater hold-up potential) obtain greater discounts when they switch. Hence, to examine this hypothesis, we reestimate our model in Column $\mathrm{V}$ after adding each of our four measures of relationship strength as an explanatory variable (i.e., we estimate $r_{\text {Switch }}-r_{\text {Not switch }}=\alpha+\beta^{*} X+\zeta$, where $\alpha$ and $\beta$ are the coefficients to be estimated, $X$ is a measure of the strength of the 
switchers' relationships with their inside banks prior to the switch, and $\zeta$ is the error term). Intuitively, this is similar to splitting the sample into two groups of switchers: those with strong relationships with their inside banks and those with weak relationships.

The estimated parameters when $X$ is equal to Prior Relationship Length are $\hat{\alpha}=36.80(30.98)$ and $\left.\hat{\beta}=-6.55^{* * *} 1.71\right)$. Hence, our estimates suggest that hold-up intensifies in relationship length, and that only switchers with prior relationships longer than 5.6 months obtain a discount when they switch. When $X$ is equal to Prior Multiple Relationships, we find that $\hat{\alpha}=-71.76^{* *}(32.46)$ and $\hat{\beta}=72.40^{*}(42.58)$, suggesting that multiple relationships soften or even eliminate hold-up problems. Additional products with the inside banks seem to exacerbate hold-up, although the estimated coefficients for Scope of the Bank Relationship are not statistically significant: $\hat{\alpha}=-53.25^{* * *}(32.46)$ and $\hat{\beta}=-46.75(74.51) .{ }^{24}$ Overall, we view these additional cross-sectional results as an important step toward a more decisive identification in favor of the hold-up hypothesis.

Next, we investigate the role of market concentration. We set $X$ equal to the $H H I$ of outstanding loans at the regional level, a measure of banking market concentration prior to switching, and find that $\hat{\alpha}=-103.20^{* * *}(22.11)$ and $\hat{\beta}=85.75^{* *}(33.92)$. Hence, if market concentration measures the intensity of competition, this result confirms predictions in von Thadden (2004). When competition is less intense, outside banks bid less aggressively for new customers, and thus switching loans carry smaller interest rate discounts.

Nevertheless, the Internet Appendix also investigates a number of alternative (that is, nonhold-up) explanations for our findings. For example, a general downward drift in interest rates (which occurs during part of the sample period) combined with loan rate stickiness at the inside bank could motivate firms to switch, which would explain our findings. Banks may also try to attract firms through temporary sales campaigns, or bank distress may cause firms to flee certain relationships. The Internet Appendix, however, shows that we find no evidence consistent with these alternative explanations.

\section{Loan Rates after Switching from the Outside Banks C.1. Main Results and Robustness Analysis}

Next, we test $\mathrm{H} 3$ by tracing the switchers over time in their new bank, and calculate the spread between the loan rate on the switching loan and the loan rate on new loans that the switcher obtained from the outside bank after the switch. The comparison is now not only within the same bank but also within the same borrower. Apart from matching on bank and borrower identity, we also match on all other variables of our benchmark model, which include credit rating and other loan conditions. This implies that we compare only the loans to switchers that remained with the new bank and whose rating did not change after the switch. 
This matching exercise yields 353 switching loans to 246 firms and 1,430 comparable future loans. More than $98 \%$ of these loans have the best rating; the rest obtain the second best. These are the firms that the outside bank originally rated highly, and that maintained their high ratings (suggesting that the bank had not been overconfident about these firms and did not have to belatedly recognize their lower true quality once they became better known). In effect, these are the "good" firms in von Thadden (2004) that are potentially exposed to holdup.

Using this sample, we group the corresponding matches in 6-month periods ("1 to 6 months" to "At least 37 months") after the switch and regress the spreads adjusted by the interbank market rate on a constant, the 6-month period dummies, and 53 calendar-time dummies (allowing the spreads to depend on the level of the market rates or other conditions that might vary over calendar time). We report the coefficients of the 6-month period dummies. As before, we cluster the standard errors at the firm level.

The estimated spreads appearing in Table IV, Panel A indicate that in the first 18 months after the switch, the loan rate drops further by up to 36 basis points, and starts increasing only afterward. After a firm switches, the "old" inside bank may update its probability of losing this firm and become more aggressive in pricing, offering lower loan rates. Hence, the outside bank may have to give additional discounts to keep the new customer. ${ }^{25}$ Once past this initial period in which the old bank is still an insider and the new bank an outsider, ${ }^{26}$ the firm starts paying higher interest rates. Three years after the switch, the loan rate on new loans is 190 basis points higher than the loan rate on the switching loan, consistent with H3.

Table IV. Spreads before and after Switching

\section{Panel A: Spreads between Interest Rates on New Loans by the Outside Bank and the Switching Loan}

\begin{tabular}{|c|c|c|c|c|c|c|c|}
\hline $\begin{array}{l}\text { Periods (in } \\
\text { months) } \\
\text { since the } \\
\text { switching } \\
\text { loan }\end{array}$ & 1 to 6 & $\begin{array}{c}7 \text { to } \\
12\end{array}$ & $\begin{array}{c}13 \text { to } \\
18\end{array}$ & $\begin{array}{c}19 \text { to } \\
24\end{array}$ & $\begin{array}{c}25 \text { to } \\
30\end{array}$ & $\begin{array}{c}31 \text { to } \\
36\end{array}$ & $\begin{array}{c}\text { At least } \\
\mathbf{3 7}\end{array}$ \\
\hline $\begin{array}{l}\text { Number of } \\
\text { switching } \\
\text { loans }\end{array}$ & 260 & 165 & 112 & 72 & 43 & 29 & 29 \\
\hline
\end{tabular}


Table IV. Spreads before and after Switching

Panel A: Spreads between Interest Rates on New Loans by the Outside Bank and the Switching Loan

\begin{tabular}{|c|c|c|c|c|c|c|c|}
\hline $\begin{array}{l}\text { Periods (in } \\
\text { months) } \\
\text { since the } \\
\text { switching } \\
\text { loan }\end{array}$ & 1 to 6 & $\begin{array}{c}7 \text { to } \\
12\end{array}$ & $\begin{array}{c}13 \text { to } \\
18\end{array}$ & $\begin{array}{l}19 \text { to } \\
24\end{array}$ & $\begin{array}{c}25 \text { to } \\
30\end{array}$ & $\begin{array}{c}31 \text { to } \\
36\end{array}$ & $\begin{array}{c}\text { At least } \\
\mathbf{3 7}\end{array}$ \\
\hline $\begin{array}{l}\text { Number of } \\
\text { future loans }\end{array}$ & 455 & 324 & 219 & 167 & 95 & 66 & 104 \\
\hline $\begin{array}{l}\text { Number of } \\
\text { observation } \\
\text { s }\end{array}$ & 587 & 378 & 267 & 198 & 114 & 84 & 131 \\
\hline \multirow{2}{*}{$\begin{array}{l}\text { Spread in } \\
\text { basis points }\end{array}$} & $\begin{array}{c}-2.0^{* *} \\
*\end{array}$ & $\begin{array}{c}-21.9 \\
*\end{array}$ & $\begin{array}{c}-36.2^{*} \\
*\end{array}$ & 31.4 & 28.2 & $60.4^{*}$ & $\begin{array}{c}190.6 * * \\
*\end{array}$ \\
\hline & $(0.0)$ & (12.6) & $(15.9)$ & $\begin{array}{c}(21.7 \\
)\end{array}$ & $\begin{array}{c}21.6 \\
)\end{array}$ & $\begin{array}{c}(36.0 \\
)\end{array}$ & $(50.5)$ \\
\hline
\end{tabular}

Panel B: Spreads between Interest Rates on Past Loans by the Inside Bank and the First Loan by the Inside Bank

1.

In Panel A, we calculate the spread between the interest rates on new loans obtained by the switching borrower from the outside bank and the interest rate on the switching loan. In Panel B, we calculate the spread between the interest rates on past loans obtained by the switching borrower from the inside bank and the interest rate on the first loan obtained from the inside bank. Apart from matching on bank and borrower identity, we also match on the relevant variables from our benchmark model in Column II of Table III (i.e., currency denomination, loan type, credit rating, region, economic activity, legal structure, collateralization, maturity, amount, and loan rate proviso). The variables are defined in Table II. We group the corresponding matches in seven half-year periods ("1 to 6" to "At least 37" months) 


\section{Panel B: Spreads between Interest Rates on Past Loans by the Inside Bank and the First Loan by the Inside Bank}

since the switching loan and regress the spreads adjusted by the interbank market rate on a constant, the seven half-year period dummies, and calendar-time dummies. We report the coefficients of the half-year period dummies. We cluster at the firm level and report robust standard errors between parentheses. $* * *$, and $* * *$ indicate significance at the $10 \%, 5 \%$, and $1 \%$ levels, two-tailed.

Periods

(in

\begin{tabular}{|c|c|c|c|c|c|c|}
\hline $\begin{array}{l}\text { months) } \\
\text { since the } \\
\text { first } \\
\text { recorded } \\
\text { loan }\end{array}$ & $\begin{array}{c}1 \text { to } \\
6\end{array}$ & 7 to 12 & 13 to 18 & $\begin{array}{c}19 \text { to } \\
24\end{array}$ & $\begin{array}{c}25 \text { to } \\
30\end{array}$ & $\begin{array}{c}31 \text { to } \\
36\end{array}$ \\
\hline
\end{tabular}

\begin{tabular}{|c|c|c|c|c|c|c|c|}
\hline $\begin{array}{l}\text { Number } \\
\text { of first } \\
\text { recorded } \\
\text { loans }\end{array}$ & 372 & 181 & 90 & 67 & 32 & 21 & 6 \\
\hline $\begin{array}{l}\text { Number } \\
\text { of future } \\
\text { loans }\end{array}$ & 1,115 & 559 & 310 & 205 & 99 & 41 & 11 \\
\hline $\begin{array}{l}\text { Number } \\
\text { of } \\
\text { observatio } \\
\text { ns }\end{array}$ & 2,992 & 1,498 & 644 & 581 & 220 & 118 & 37 \\
\hline $\begin{array}{l}\text { Spread in } \\
\text { basis } \\
\text { points }\end{array}$ & $\begin{array}{c}-4.9 \\
(4 . \\
9)\end{array}$ & $\begin{array}{c}-47.2 * \\
* * \\
(15.1)\end{array}$ & $\begin{array}{c}-103.8^{*} \\
* * \\
(16.3)\end{array}$ & $\begin{array}{c}-67.0 \\
* \\
(40 . \\
0)\end{array}$ & $\begin{array}{c}96.1 * * \\
* \\
(20.2)\end{array}$ & $\begin{array}{c}120.8 * \\
* * \\
(45.5)\end{array}$ & $\begin{array}{c}128.6 * \\
* \\
(59.6)\end{array}$ \\
\hline
\end{tabular}

As a robustness check, rather than looking forward, we look backward and investigate whether a loan rate cycle (similar to the one identified among the outside banks) can also be traced in the loans that switchers obtained from their inside banks before the switch. We thus 
identify all of the loans that a switcher obtained from its inside bank and compare the loan rate on the first recorded loan from a given bank with all subsequent loans from that bank using the same specifications as in the forward exercise. Table IV, Panel B reports the estimated coefficients of the group dummies. The resulting loan rate pattern is similar to the one identified in Panel A, despite the fact that we are compelled to mix relationships of various lengths. Early on, the loan rate drops; it then levels off, and subsequently increases, as in Panel A.

Figure 4 displays the resulting loan rate pattern. The figure contains the coefficient estimates

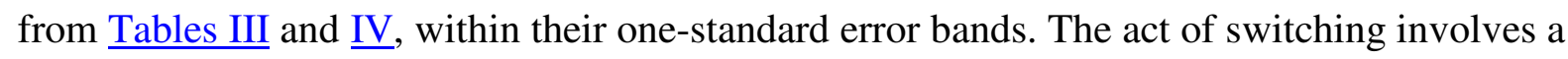
rate reduction of 87 basis points (estimates from Column II of Table III). As the matched estimates in Table IV are anchored to this decrease, the estimates suggest that the rate differential returns back to zero more than 3 years after the switch. The estimated median length of an observed relationship is almost 5 years. Hence, a year and a half after the median firm starts paying "hold-up rents," it switches again to another bank. Banks recoup the initial discounts by charging higher loan rates later on. Our estimates suggest that 5 years after the switch banks break even. ${ }^{27}$ The dynamic pattern we identify and the distinct firm and bank break-even periods pose an interesting question for future theoretical work.

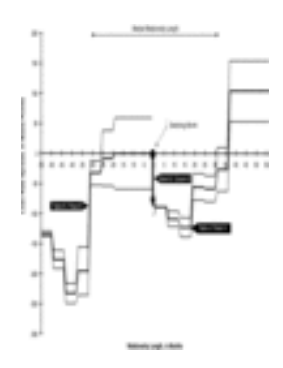

Figure 4. Spread before and after switching. The figure displays the spread (in basis points) between the interest rate on new loans obtained by the switcher and interest rates on loans obtained by matched firms from inside or outside banks before, around, and after the switch. The solid lines are the coefficient estimates from Tables III (Column II) and IV, while the dashed lines indicate minus and plus one standard error around the coefficient estimate. The estimates of Table IV (Panel A) are anchored at the -87 spread from Table III (Column II). The estimates of Table IV (Panel B) are anchored at zero. The horizontal arrowed line indicates the estimated median length of relationships in the sample.

\section{$\underline{\text { Download figure to PowerPoint }}$}

All in all, our matching exercises suggest that good firms eventually pay a substantially higher loan rate the longer they borrow from the same bank, in line with the informational lock-in present in von Thadden (2004). The consistency of the results before and after a switch gives 
further credence to the presence of a distinct loan rate cycle in the data and provides a possible explanation for the mixed findings in the existing empirical literature.

\section{C.2. Hold-Up and Alternative Explanations}

To advance us further toward decisive identification of hold-up, we also explore the effect of a number of key variables on the loan rate dynamics. For example, the extent to which the outside banks are able to extract rents from their new customers should depend on the strength of their relationship with those customers. For example, the hold-up potential should be lower for switchers that maintain active lending relationships with their "old" inside banks.

To investigate this hypothesis, we estimate $r_{\text {Switch }}-r_{\text {Not-switch }}=\alpha+\beta * X+\gamma_{1} * T+\gamma_{2} * T^{2}+\delta_{1} * X * T$ $+\delta_{2} * X * T^{2}+\zeta$, where $\alpha, \beta, \gamma_{1}, \gamma_{2}, \delta_{1}$, and $\delta_{2}$ are the coefficients to be estimated, $X$ is a measure of relationship strength or the degree of local market concentration, $T$ is the time in months since the switch, and $\zeta$ is the error term. We find that when $X$ is equal to Multiple Bank Relationships, the estimated coefficients suggest that maintaining multiple relationships softens (but does not eliminate) hold-up ( $\hat{\gamma}_{1}=-8.98^{* * *}, \hat{\gamma}_{2}=0.32^{* * *}, \hat{\delta}_{1}=7.02^{*}$, and $\hat{\delta}_{2}=-0.18^{* *}$, with $\hat{\gamma}_{1}+\hat{\delta}_{1}=-1.96$ and $\left.\hat{\gamma}_{2}+\hat{\delta}_{2}=0.14^{* *}\right)$. When $X$ is equal to Scope of the Bank Relationship or Primary Lender, the estimated coefficients on the interaction terms do have the expected signs, but they are not statistically significant.

To investigate the role of market concentration on the loan rate cycle, we also set $X$ equal to $H H I$ and find that the cycle is less pronounced in more concentrated markets $\left(\hat{\gamma}_{1}=-25.43^{* * F}\right.$, $\hat{\gamma}_{2}=0.80^{* * *}, \hat{\delta}_{1}=132.22^{* * *}$, and $\hat{\delta}_{2}=-3.81^{* *}$ ). If market concentration measures competition, then these results suggest that in more competitive markets banks bid more aggressively to attract new customers and recoup these discounts from the subset of borrowers they hold up later on. Banks seeking to attract new customers in less competitive markets do not need to be as aggressive, and rates subsequently do not increase as much. Note, however, that the level of interest rates in such markets could still be higher.

Finally, we also investigate a possible alternative explanation for our findings in Table IV. Specifically, if better firms tend to borrow again sooner or more frequently than worse firms, then the dynamic pattern of interest rates that we observe in Table IV could be due to changes in firm quality, which is not captured by the variables we match on. Limiting the sample to firms that borrow again within 6 (12) months after the switch leaves us with 76\% (89\%) of the sample firms (which is not surprising given that the median loan maturity is only 6 months), but results are virtually unaffected (see the Internet Appendix).

\section{C.3. Other Loan Conditions}


We also investigate the change in three other loan characteristics around and after switching. We match on all previously employed variables now including Loan Rate. The results are reported in Panel A, Table V (we repeat the results of our benchmark model for the loan rate in Column I). We find that switching loans are more collateralized, have longer maturities, and are larger in size (loan amounts continue to increase until 1 year after the switch). While the maturity on future outside loans decreases again more than 3 years after the switch (Panel B), the other two loan characteristics do not change in a statistically significant way.

Table V. Differences in Loan Conditions on Switching Loans and Matched Loans Given by Inside Banks

Matching Variables
I

Loan

Rate
II

III

IV

$\begin{array}{ccc}\begin{array}{c}\text { Proportion of } \\ \text { Loan }\end{array} & \begin{array}{c}\text { Loan } \\ \text { Maturity }\end{array} & \begin{array}{c}\text { Loan } \\ \text { Amount }\end{array} \\ \text { Collateralized } & \text { Maturitat }\end{array}$

\section{Panel A: The Difference in Loan Condition on a Switching Loan and New Loans Obtained (by Other Firms) from the Switchers' Set of inside Banks}

Year: month, bank, currency denomination, loan type, floating loan Yes Yes Yes Yes

rate, credit rating, region, economic activity, legal structure

Loan rate Yes

Yes

Yes

Proportion of loan collateralized Yes Yes Yes

Loan maturity Yes Yes Yes

Loan amount Yes Yes Yes

Value-weighted by borrower/inside bank Yes Yes Yes Yes loans 
Table V. Differences in Loan Conditions on Switching Loans and Matched Loans Given by Inside Banks

$\begin{array}{ccccc} & \text { I } & \text { II } & \text { III } & \text { IV } \\ \text { Matching Variables } & \begin{array}{c}\text { Loan } \\ \text { Rate }\end{array} & \begin{array}{c}\text { Proportion of } \\ \text { Loan }\end{array} & \begin{array}{c}\text { Loan } \\ \text { Collateralized }\end{array} & \begin{array}{c}\text { Maturity } \\ \text { Amount }\end{array} \\ & & \text { Amon }\end{array}$

\section{Panel A: The Difference in Loan Condition on a Switching Loan and New Loans Obtained (by Other Firms) from the Switchers' Set of inside \\ Banks}

Number of switching loans

Number of

nonswitching loans

Number of

observations (matched

pairs)

Difference in loan conditions (at time of the switching loan)
276

609

820

$-86.9 * * *$

$(17.5)$
285

325

317

Panel B: Difference in Loan Condition on New Loans Obtained by the Switching Borrower from the Outside Bank and the Switching Loan

In Panel A, we assess the difference in each loan condition on a switching loan and the loan condition on new loans obtained (by other firms) from the switchers' set of inside banks. We match on the indicated variables (similar to the benchmark model in Column II of Table III). The variables are defined in Table II. We regress the difference in each loan condition on a constant and report the coefficient on the constant. We cluster at the switching-firm level and report robust standard errors between parentheses. The results for the loan rate are also in Table III, Column II. In Panel B, we calculate the 


\section{Panel B: Difference in Loan Condition on New Loans Obtained by the Switching Borrower from the Outside Bank and the Switching Loan}

difference in each loan condition on new loans obtained by the switching borrower from the outside bank and the loan condition on the switching loan. We match on the indicated variables (similar to the benchmark model in Column II of Table III). We group the corresponding matches in 6-month periods ("1 to 6 " to "At least 37" months) since the switching loan and regress the spreads adjusted by the interbank market rate on a constant, the group dummies, and 53 calendar-time dummies. We report the coefficients of the group dummies. We cluster at the firm level but do not report the robust standard errors. The results for the loan rate are also in Table IV, Panel A. $* * *$, and $* * *$ indicate significance at the $10 \%, 5 \%$, and $1 \%$ levels, two-tailed.

1 to 6 months since

the switching loan

$$
-2.0
$$

$-2.56$

$-18,870$

7 to 12

$-21.9 *$

3.58

3.65

$116,652 * *$

13 to 18

$-36.2 * *$

$-1.20$

2.23

158,689

19 to 24

31.4

21.67

4.39

380,635

25 to 30

28.2

$-8.37$

3.75

293,430

31 to 36

$60.4^{*}$

$-36.08$

$-5.78$

348,297

At least 37

$190.6^{* * * *}$

$-15.13$

$-9.05^{* *}$

900,641

Overall, with the exception of collateral our findings suggest that switching initially involves better loan conditions, but that afterward conditions seem to tighten up again. One possible reason switching loans are more likely to be collateralized is because collateral is used by outside banks to mitigate ex ante information asymmetries between borrowers and lenders (see Bester (1985), Besanko and Thakor (1987), and Chan and Thakor (1987), for example). Nevertheless, information asymmetries will persist if the borrowers' "collateralizable" wealth restricts the design of loan contracts as selection mechanisms (Bester (1987)).

\section{Adverse Selection: Loan Repayment and Information Sharing}


Our final hypothesis, $\mathrm{H} 4$, posits that (because of adverse selection) a larger proportion of switching firms is worse in terms of unobservable risk characteristics than a random draw of the population. To investigate this hypothesis, Figure 5 compares the repayment history of switchers and nonswitchers. After first comparing the entire population of switching and nonswitching firms, we then compare a subsample of matched firms.

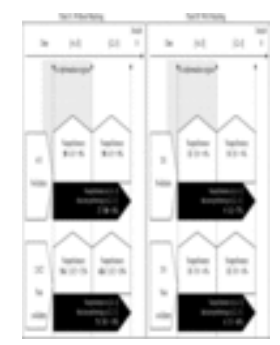

Figure 5. Information sharing and number of switchers with nonperforming loans. The figure displays the number of switchers (top row) and nonswitchers (bottom row) with nonperforming and performing loans for the various time periods indicated with vertical arrows and labeled at the bottom. The black boxes provide ratios of conditional performance. Using a standard Pearson Chi-square test, equality of the proportions between the various groups of switchers and nonswitchers can be rejected at the $1 \%$ level of significance for all groups without matching.

\section{$\underline{\text { Download figure to PowerPoint }}$}

Comparing the entire population of switching and nonswitching firms, we find that switchers are on average better performers. In the 2 months prior to the switch, only $8 \%$ of the 615 switchers do not perform (i.e., have overdue payments on one of their outstanding loans). In contrast, $26 \%$ of the 2,422 nonswitchers do not perform during the same period, suggesting that outside banks (compared to inside banks) are less willing to extend credit to borrowers with observable repayment problems. If past nonperformance is predictive of future nonperformance, these results also suggest that the information-sharing that takes place through the registry helps outside banks select mostly good firms.

However, a look at the percentage of firms that improved just prior to the 2-month common information window reveals an interesting pattern. We find that $54 \%$ of the switchers with nonperformance in the $[-4,-3]$ period become performing during the critical $[-2,-1]$ period. In sharp contrast, the corresponding figure for nonswitchers is only $14 \%$. This pattern suggests that firms use this common information window strategically (i.e., since the outside banks are reluctant to extend credit to firms with observable repayment problems, firms with problems in $[-4,-3]$ that want to switch make their due payments just prior to the $[-2,-1]$ period). 
While these substantial differences in the conditional repayment figures are consistent with H4 (i.e., compared to nonswitchers, a larger proportion of switchers has unobservable repayment problems), these differences may also be due to other observable differences between the two groups. Hence, we reproduce our analysis for a subsample of matched switching and nonswitching firms using our benchmark model (i.e., we match on bank, month, firm, and loan characteristics as in Column II of Table III). Although the two groups are now much more similar, we still find that $75 \%$ of the switching firms with repayment problems in $[-4,-3]$ become performing during the critical $[-2,-1]$ period, while the corresponding figure for nonswitchers is only $46 \%$, still consistent with $\mathrm{H} 4 . \underline{28}$

Overall, these results suggest that the information-sharing regime assures that mostly performing firms can switch, a result that is in line with general theoretical priors such as Jappelli and Pagano (1993) and Padilla and Pagano (1997, 2000). Nevertheless, some nonperformers adversely mix with performers by making a good appearance during the 2month information period, suggesting that some information asymmetries remain. Additional results provided in the paper and in the Internet Appendix further support this hypothesis (e.g., information rents are larger for firms with stronger relationships with their banks, and ratings become better predictors of ex post loan performance as the length of the bank-firm relationship increases).

Jump to...

IV. Conclusion

1. Top of page

2. ABSTRACT

3. I. Hypotheses and Related Literature

4. II. Data and Descriptive Statistics

5. III. Results

6. IV. Conclusion

7. REFERENCES

Using the Bolivian credit registry between 1999 and 2003, we study the loan conditions and bank-firm behavior right before and after a firm switches to a new bank.

We find that turning to a new bank leads to a substantial drop in the loan rate: 87 basis points at switching time followed by an additional 36 basis points on new loans obtained within the next year and a half. However, after this period, the "new" (now inside) bank starts increasing its loan rate-even if the firm's financial condition has not deteriorated. After around 3 years the switching firm is back to where it started (i.e., the loan rate charged by the new bank now equals what the switcher obtained from its inside banks before switching). Other loan 
conditions follow a similar economically relevant pattern. Consequently, the firm will eventually (when its observable financial performance allows) start looking for more favorable conditions at other banks. We also find that firms with short or multiple relationships and firms in more concentrated regional banking markets obtain smaller discounts when they switch and have a shallower loan rate cycle.

The information-sharing regime in place allows the outside banks to select mostly performing firms. However, since the information available in the credit register covers only the past 2 months, the outside banks still suffer from adverse selection: some "bad" firms make their due payments for 2 months and manage to switch, but return to nonperformance soon thereafter.

The better loan conditions a firm obtains upon switching, the subsequent tightening of conditions (possibly due to informational lock-in), and the presence of adverse selection due to limited information-sharing corroborate key elements in modern banking theory (Sharpe (1990), Rajan (1992), and von Thadden (2004), for example). More empirical research is warranted to investigate more deeply the effects of key institutional characteristics on the documented loan rate patterns and bank-firm behavior in credit markets.

Footnotes

- 1

Hold-up costs are also present in Rajan (1992), since in his model the bank has the power to withdraw financing when it perceives the firm to be inadequately managed. This degree of control can be costly because it reduces the incentives of the firm manager to exert effort. In Hauswald and Marquez (2003, 2006), the informational advantage is differentiated across banks. See also Egli, Ongena, and Smith (2006), Black (2008), and Karapetyan and Stacescu (2008).

\section{- 2}

von Thadden (2004) assumes that firms switch when the offer is strictly lower. However, his model also demonstrates that offers that are strictly lower will most likely occur. See Black (2008) for an incisive discussion.

- 3

If lending costs decrease in relationship length, their evidence would suggest that banks extract rents, which would be consistent with the hold-up hypothesis. Rates remain constant also in Elsas and Krahnen (1998), Harhoff and Körting (1998), and D'Auria, Foglia, and Reedtz (1999). 
Most studies assume that the collateral and maturity decisions are taken either independently or sequentially after the loan-granting decision but before the determination of the loan rate. Ignoring the joint character of the loan decision may bias the findings (Berger et al. (2005), Brick and Palia (2007), and Ortiz-Molina and Penas (2008)). By matching on collateral and loan maturity, we do not need to assume anything about the decision process. Most studies also ignore loan fees ( $\mathrm{HaO}(2003))$ and the pricing implications of cross-selling (Liberti (2004)). By matching on bank, time, type of loan, relationship, and loan characteristics, we control for loan fees and cross-selling (assuming banks at the same point in time apply the same fees and crossselling practices to similar loans and borrowers with similar relationship characteristics). Matching is nonparametric and does not incorporate information from outside the overlap region between the treatment and control groups.

- 5

Some recent papers also compare the rates on loans from a firm's inside or outside bank. Results in these studies are also mixed. Using an Italian survey, Barone, Felici, and Pagnini (2006) find that rates are between 25 and 123 basis points lower after a switch. On the other hand, analyzing the U.S. Survey of Small Business Finance, Black (2006) finds that interest rates on outside loans are on average 40 basis points higher than loans from existing banks. However, none of these studies analyze the development of loan conditions around switching by matching new loan initiations on multiple bank, loan, and firm characteristics.

- 6

Other databases employed in studies by Ongena and Smith (2001), Farinha and Santos (2002), and Gopalan, Udell, and Yerramilli (2007), for example, lack crucial loan contract information (such as the loan rate), report only at a quarterly or yearly frequency, and/or cover only part of all corporate borrowing (both across firms and credit products).

- 7

Limiting "the amount of data made available for distribution to the financial institutions to the current month" is common in many countries (see Miller (2003), Table 1A.7, Column 3). Administrative costs and regulatory objectives may explain the short information-sharing window. A 2-month window seems too short to achieve optimal memory loss à la Vercammen (1995). 
Bolivia's corporate sector is segmented. It is composed of a few formal firms and a multitude of very small firms, most of which are single-person businesses that remain informal. The formal firms have access to commercial bank credit, while the very small firms can borrow only from informal institutions (e.g., microfinance NGOs and foundations), which do not report to the CIRC. This was the situation until April 2000, as the Bolivian law prohibited the creation of private credit bureaus (Campion (2001)). Following the change in the law, other private bureaus specializing in micro and consumer credit were created, but were not operational as of December 8, 2003 (de Janvry et al. (2003)).

- 9

To keep the set of financial institutions homogeneous in terms of financial structure and regulation, we focus on loans from commercial banks and exclude loans from other formal nonbank institutions (such as private financial funds, credit unions, mutual societies, and general deposit warehouses). Since the late 1980s, all commercial banks are privately owned. Banks are also prohibited from owning nonfinancial firms (Barth, Caprio, and Levine (2006)). We start the sample period in March 1999 because prior to this date we cannot distinguish between commercial and consumer loans. The sample period is characterized by an economic slowdown. The average growth rate of real GDP is $2.2 . \%$, substantially lower than the average $4.5 \%$ growth rate of the previous 5 years.

- 10

More than $90 \%$ of all deposits and credits in Bolivia are denominated in US\$. Because the economy is highly dollarized, the exchange rate policy follows a crawling peg with the US\$. During the sample period the Bolivian peso was depreciating with respect to the US\$ at a constant, predetermined rate. We translate the loan amounts in Bolivian pesos and report all loan amounts in US\$.

- 11

As information on total firm assets is not available, we approximate firm size with total bank debt. Using data from the SSBF for the United States, Petersen and Rajan (1994) find that, conditional on the existence of institutional debt, the ratio of bank debt to total debt does not vary significantly with firm size. For firms with less than $\$ 15,000$ in total assets, this ratio is equal to $51 \%$, while for firms with more than $\$ 2,000,000$ in total assets the ratio equals $62 \%$. Since capital markets are less 
developed in Bolivia than in the United States, this ratio may vary even less, such that total bank debt is most likely highly correlated with firm size.

- 12

See Petersen and Rajan (1994) for the United States, Harhoff and Körting (1998) for Germany, Degryse and Van Cayseele (2000) for Belgium, Ongena and Smith (2001) for Norway, and Farinha and Santos (2002) for Portugal.

- 13

Although the incidence of collateral is low, the proportion of the loan that is collateralized (i.e., the value of collateral to the loan amount) appears quite large. Collateral values are on average six times larger than the loan amounts, and $70 \%$ of the loans that are collateralized have collateral values larger than the loan amount. The collateral values that are recorded in the registry indicate the estimated market value of the collateralized assets at the time of the loan origination. Typically, such values are higher than the amounts banks are able to recover in the event of bankruptcy. Hence, even fully collateralized loans could still carry a positive loss in the event of defaulta prerequisite for von Thadden (2004) to be applicable. Nevertheless, in a sensitivity analysis we also investigate the robustness of our findings in the subsample of loans without collateral.

- 14

Moving versus adding a relationship may differ for newly created firms (Farinha and $\underline{\text { Santos (2002)) or for firms that switch following bank mergers (Degryse, }}$ Masschelein, and Mitchell (2009)). As we analyze only firms that had an inside bank, de novo firms are unlikely to play an important role in our sample. No bank mergers took place during or immediately prior to the sample period, but we investigate the robustness of our results to the exclusion of firms that were borrowing from three banks that failed just prior to or during the sample period (as some of those banks' assets were transferred to other banks). As discussed later, we find no changes in our results.

- 15

Given the number of observations available, we rely on matching rather than on a propensity score (as in Dehejia and Wahba (2002), for example). The score methodology is often criticized because the same score may be given to items with very different characteristics. 
As discussed later, rating biases may exist because of information asymmetries between inside and outside banks, the observability of ratings to other banks through the credit registry, and loan loss provisioning.

- 17

If switching costs contain a transactional component that varies across borrowers (as in Bouckaert and Degryse (2006)), then our estimates would provide only a lower bound on total switching costs, since borrowers with higher costs would not switch.

- 18

In the Internet Appendix, we subject this specification to a series of robustness checks. We first reestimate the model as follows: using fewer matching variables, without weighting the observations, dropping firms that got an inside loan in the same month of the switch (since these firms might be switching for other reasons), using only loans without collateral, and using one observation per switching loan. The latter is possible if instead of using each matched pair, we calculate the spread using the difference between each switching loan and the median interest rate of its matched loans. In all cases, results are very similar. We also reestimate the model after matching consecutively on the total amount of outstanding debt as a proxy for firm size, relationship characteristics with the new bank using Multiple Relationships, Primary Bank, and Scope of the Bank Relationship as defined in Table II, and borrower identity. The number of observations declines gradually to only 40 observations, but the estimated spreads remain very similar-although not always statistically significant.

The change in the sample of the switching loans (as a result of changes in the matching variables) affects the difference between matched and unmatched spreads. Adding matching variables reduces the set of loans that qualify and has the salutary effect of dropping loans with rarer characteristics for which a match cannot be found. It is a priori not clear if these smaller subsamples are less heterogeneous, as there may be a few common loan types that are very different from each other. However, heterogeneity will eventually dissipate, bringing the wedge between the matched and unmatched spreads down to zero (consider the limiting case of a single pair). 
We also subjected this model to the same series of robustness checks as the model presented in Column I. The results are in all cases very similar and are presented in the Internet Appendix.

- 21

This finding suggests that borrower heterogeneity is higher when we match using loans from the outside banks. Although in von Thadden (2004) the outside banks do not have existing customers, outside banks in reality may aim to diversify by attracting switchers that are different from their existing customers.

- 22

Additional results presented in the Internet Appendix suggest that the outside banks do not seem to bother to rate their new customers (i.e., they give the best rating to almost all of their new customers) and, consistent with A2, rely on the inside banks' observable ratings for their pricing. Evaluating new customers should be very expensive, as very little information is known outside a bank-firm relationship or the credit registry. If outside banks recognize their informational disadvantage vis-à-vis the inside banks, then assigning the top rating while using the inside banks' more conservative ratings for pricing might be very attractive-as it also reduces loan loss provisioning.

- 23

In the case of multiple inside ratings or loan rates (in Columns III and IV), we used the worst rating or the highest loan rate. Results are robust to using the average or the best rating/loan rate (see the Internet Appendix). The same holds for the counterparts of the model presented in Column I of Table III (see the Internet Appendix).

- 24

We do not estimate the model using Prior Primary Lender as an independent variable, since it is equal to one for $99 \%$ of the observations in this matched sample.

- 25

Though not explicitly modeled, additional rate cuts may be consistent with the general model intuition in von Thadden (2004).

- 26 
The length of this period during which the bank may be collecting additional inside information seems similar to the 1-year period documented in Cole (1998).

- 27

The average yearly switching rate for active loan-initiating firms equals $13.6 \%$ (for all firms it is $10.6 \%$ ). Assuming constant duration dependence, the resulting median duration is 5 (6) years. If duration dependence is positive (Ongena and Smith (2001)), then the estimated median duration will be shorter. Integrating the estimated loan rate spread over time (i.e., multiplying the estimated loan rate spread times the length of the period for which it is estimated) puts the break-even point at 63 months.

- 28

In the Internet Appendix, we also show that both observable and unobservable past repayment problems are predictive of repayment problems in future loans.

Unobservable repayment problems remain predictive of future nonperformance-even if we control for observable repayment problems - which suggests that this adverse unobservable information about the firm could help outside banks better select and price loans for their customers.

\section{REFERENCES}

1. Top of page

2. ABSTRACT

3. I. Hypotheses and Related Literature

4. II. Data and Descriptive Statistics

5. III. Results

6. IV. Conclusion

7. REFERENCES

- Barone, Guglielmo, Roberto Felici, and Marcello Pagnini, 2006, Switching costs in local credit markets, Working paper, Banca d'Italia .

- Barth, James, Gerard Caprio, and Ross Levine, 2006. Rethinking Bank Regulation: Till Angels Govern (Cambridge University Press, Cambridge, UK ).

- University of Zurich

- Berger, Allen N., Marco Espinosa-Vega, W. Scott Frame, and Nathan M. Miller, 2005, Debt maturity, risk, and asymmetric information, Journal of Finance 60, 2895-2924. 
Direct Link:

- $\underline{\text { Abstract }}$

- Full Article (HTML)

$\circ \quad \underline{\operatorname{PDF}(158 \mathrm{~K})}$

$\circ \quad \underline{\text { References }}$

- Web of Science® Times Cited: 15

- University of Zurich

- Berger, Allen N., and Gregory F. Udell, 1995, Relationship lending and lines of credit in small firm finance, Journal of Business 68, 351-381.

- CrossRef,

- Web of Science ${ }^{\circledR}$ Times Cited: 306

$\circ \quad$ University of Zurich

- Berger, Allen N., and Gregory F. Udell, 2002, Small business credit availability and relationship lending: The importance of bank organisational structure, Economic Journal 112, 32-53.

Direct Link:

- $\underline{\text { Abstract }}$

- Full Article (HTML)

- $\underline{\operatorname{PDF}(213 \mathrm{~K})}$

- $\quad$ References

- Web of Science® Times Cited: 40

- University of Zurich

- Besanko, David, and Anjan V. Thakor, 1987, Competitive equilibrium in the credit market under asymmetric information, Journal of Economic Theory 42, 167-183.

- CrossRef,

- Web of Science® Times Cited: 63

- University of Zurich

- Bester, Helmut, 1985, Screening vs. rationing in credit markets with imperfect information, American Economic Review 75, 850-855.

- Web of Science ${ }^{\circledR}$ Times Cited: 194 
$\circ \quad$ University of Zurich

- Bester, Helmut, 1987, The role of collateral in credit markets with imperfect information, European Economic Review 31, 887-899.

- CrossRef,

- Web of Science® Times Cited: 69

- University of Zurich

- Bhattacharya, Sudipto, and Gabriella Chiesa, 1995, Proprietary information, financial intermediation, and research incentives, Journal of Financial Intermediation 4, 328 357.

- CrossRef,

- Web of Science® Times Cited: 69

- University of Zurich

- Black, Lamont K., 2006, An empirical analysis of insider rates vs. outsider rates in bank lending, Working paper, Federal Reserve Board.

- Black, Lamont K., 2008, Insider rates vs. outsider rates in bank lending, Finance and Economics Discussion Paper 36, Federal Reserve Board.

- Boot, Arnoud W. A., 2000, Relationship banking: What do we know Journal of Financial Intermediation 9, 3-25.

- CrossRef,

- Web of Science® Times Cited: 141

- University of Zurich

- Boot, Arnoud W. A., and Anjan V. Thakor, 1994, Moral hazard and secured lending in an infinitely repeated credit market game, International Economic Review 35, 899920.

- CrossRef,

- Web of Science® Times Cited: 78

- University of Zurich

- Bouckaert, Jan, and Hans Degryse, 2006, Entry and strategic information display in credit markets, Economic Journal 116, 702-720.

Direct Link:

- $\underline{\text { Abstract }}$ 
- Full Article (HTML)

$\circ \underline{\operatorname{PDF}(159 \mathrm{~K})}$

$\circ \quad \underline{\text { References }}$

- Web of Science® Times Cited: 3

- University of Zurich

- Brick, Ivan. E., and Darius Palia, 2007, Evidence of jointness in the terms of relationship lending, Journal of Financial Intermediation 16, 452-476.

- CrossRef,

- Web of Science® Times Cited: 7

- University of Zurich

- Campbell, Tim S., 1979, Optimal investment financing decisions and the value of confidentiality, Journal of Financial and Quantitative Analysis 14, 232-257.

- University of Zurich

- Campion, Anita, 2001, Client information sharing in Bolivia, Journal of Microfinance 3, 45-63.

- University of Zurich

- Chan, Yuk-Shee, and Anjan V. Thakor, 1987, Collateral and competitive equilibria with moral hazard and private information, Journal of Finance 42, 345-363.

- CrossRef,

- Web of Science® Times Cited: 40

- University of Zurich

- Chemmanur, Thomas J., and Paolo Fulghieri, 1994, Reputation, renegotiation and the choice between bank loans and publicly traded debt, Review of Financial Studies 7, 475-506.

- CrossRef,

- Web of Science $®$ Times Cited: 67

- University of Zurich

- Cole, Rebel A., 1998, The importance of relationships to the availability of credit, Journal of Banking and Finance 22, 959-977.

- CrossRef,

- Web of Science® Times Cited: 71 
- University of Zurich

- D’Auria, Claudio, Antonella Foglia, and Paolo Marullo Reedtz, 1999, Bank interest rates and credit relationships in Italy, Journal of Banking and Finance 23, 1067-1093.

- CrossRef,

- Web of Science® Times Cited: 19

- University of Zurich

- De Janvry, Alain, Elisabeth Sadoulet, Craig McIntosh, Bruce Wydick, Jill Luoto, Gustavo Gordillo, and Guilherme Schuetz, 2003, Credit bureaus and the rural microfinance sector: Peru, Guatemala, and Bolivia, Joint Project with FAO, The University of California at Berkeley.

- Degryse, Hans, Moshe Kim, and Steven Ongena, 2009. Microeconometrics of Banking: Methods, Applications and Results (Oxford University Press, New York).

$\circ \underline{\text { CrossRef }}$

- University of Zurich

- Degryse, Hans, Nancy Masschelein, and Janet Mitchell, 2009, Staying, dropping, or switching: The impacts of bank mergers on small firms, Review of Financial Studies, DOI: $10.1093 / r f s / h h p 126$.

- University of Zurich

- Degryse, Hans, and Steven Ongena, 2005, Distance, lending relationships, and competition, Journal of Finance 60, 231-266.

Direct Link:
- $\underline{\text { Abstract }}$
- Full Article (HTML)
$\circ \underline{\operatorname{PDF}(177 \mathrm{~K})}$
$\circ \quad \underline{\text { References }}$
- Web of Science® Times Cited: 48
- University of Zurich

- Degryse, Hans, and Steven Ongena, 2008, Competition and regulation in the banking sector: A review of the empirical evidence on the sources of bank rents, in Anjan V.Thakor, and Arnoud W. A.Boot, eds. Handbook of Financial Intermediation and Banking (Elsevier, Amsterdam).

- University of Zurich 
- Degryse, Hans, and Patrick Van Cayseele, 2000, Relationship lending within a bankbased system: Evidence from European small business data, Journal of Financial Intermediation 9, 90-109.

- CrossRef,

- Web of Science® Times Cited: 71

$\circ \quad \underline{\text { University of Zurich }}$

- Dehejia, Rajeev H., and Sadek Wahba, 2002, Propensity score-matching methods for nonexperimental causal studies, Review of Economics and Statistics 84, 151-161.

$\circ$ CrossRef,

- Web of Science® Times Cited: 249

- University of Zurich

- Diamond, Douglas W., 1991, Monitoring and reputation: the choice between bank loans and privately placed debt, Journal of Political Economy 99, 689-721.

- CrossRef,

$\circ \quad$ Web of Science ${ }^{\circledR}$ Times Cited: 281

- University of Zurich

- Egli, Dominik, Steven Ongena, and David C. Smith, 2006, On the sequencing of projects, reputation building, and relationship finance, Finance Research Letters 3 , 23-39.

- $\underline{\text { CrossRef }}$

- University of Zurich

- Elsas, Ralf, and Jan Pieter Krahnen, 1998, Is relationship lending special? Evidence from credit-file data in Germany, Journal of Banking and Finance 22, 1283-1316.

- CrossRef,

- Web of Science® Times Cited: 62

- University of Zurich

- Farinha, Luisa A., and João A. C. Santos, 2002, Switching from single to multiple bank lending relationships: Determinants and implications, Journal of Financial Intermediation 11, 124-151.

- CrossRef,

- Web of Science® Times Cited: 32

- University of Zurich 
- Gopalan, Radhakrishnan, Gregory F. Udell, and Vijay Yerramilli, 2007, Why do firms switch banks? Working paper, Indiana University .

- Hao, Li, 2003, Bank effects and the determinants of loan yield spreads, Working paper, York University .

- Harhoff, Dietmar, and Timm Körting, 1998, Lending relationships in GermanyEmpirical evidence from survey data, Journal of Banking and Finance 22, 1317-1353.

- CrossRef,

- Web of Science® Times Cited: 80

- University of Zurich

- Hauswald, Robert, and Robert Marquez, 2003, Information technology and financial services competition, Review of Financial Studies 16, 921-948.

- CrossRef,

- Web of Science® Times Cited: 21

- University of Zurich

- Hauswald, Robert, and Robert Marquez, 2006, Competition and strategic information acquisition in credit markets, Review of Financial Studies 19, 967-1000.

- CrossRef,

- Web of Science® Times Cited: 22

- University of Zurich

- Jappelli, Tullio, and Marco Pagano, 1993, Information sharing in credit markets, Journal of Finance 63, 1693-1718.

$\circ \quad$ University of Zurich

- Karapetyan, Artashes, and Bogdan Stacescu, 2008, Information sharing and information acquisition in the credit industry, Working paper, Harvard University.

- Liberti, José M., 2004, Initiative, incentives and soft information: How does delegation impact the role of bank relationship managers? Working paper, Kellogg School of Management Northwestern .

- Miller, Margaret J., 2003, Credit reporting systems around the globe: The state of the art in public credit registries and private credit reporting firms, in Margaret J.Miller, ed. Credit Reporting Systems and the International Economy (MIT Press, Cambridge, $M A)$.

- University of Zurich 
- Ongena, Steven, and David C. Smith, 2001, The duration of bank relationships, Journal of Financial Economics 61, 449-475.

- CrossRef,

- Web of Science® Times Cited: 33

$\circ \quad \underline{\text { University of Zurich }}$

- Ortiz-Molina, Hernan, and M. Fabiana Penas, 2008, Lending to small businesses: The role of loan maturity in addressing information problems, Small Business Economics 30, 361-383.

- CrossRef,

- Web of Science® Times Cited: 7

- University of Zurich

- Padilla, A. Jorge, and Marco Pagano, 1997, Endogenous communication among lenders and entrepreneurial incentives, Review of Financial Studies 10, 205-236.

- CrossRef,

- Web of Science® Times Cited: 34

- University of Zurich

- Padilla, A. Jorge, and Marco Pagano, 2000, Sharing default information as a borrower discipline device, European Economic Review 44, 1951-1980.

- CrossRef,

- Web of Science® Times Cited: 22

- University of Zurich

- Petersen, Mitchell A., and Raghuram G. Rajan, 1994, The benefits of lending relationships: Evidence from small business data, Journal of Finance 49, 3-37.

- CrossRef,

- Web of Science ${ }^{\circledR}$ Times Cited: 456

- University of Zurich

- Pozzolo, Alberto Franco, 2004, The role of guarantees in bank lending, Working paper, Ente Luigi Einaudi .

- Rajan, Raghuram G., 1992, Insiders and outsiders: The choice between informed and arm's-length debt, Journal of Finance 47, 1367-1400.

- CrossRef,

- Web of Science® Times Cited: 423 
$\circ \quad$ University of Zurich

- Schenone, Carola, 2010, Lending relationships and information rents: Do banks exploit their information advantages Review of Financial Studies 23, 1149-1199.

- CrossRef,

- Web of Science® Times Cited: 1

- University of Zurich

- Sharpe, Steven A., 1990, Asymmetric information, bank lending and implicit contracts: A stylized model of customer relationships, Journal of Finance 45, 1069-1087.

- CrossRef,

- Web of Science® Times Cited: 265

$\circ \quad$ University of Zurich

- Sirtaine, Sophie, Ilias Skamnelos, and Sissi Frank, 2004, Bolivia: Challenges in the Corporate and Banking Sectors (World Bank, Washington, DC ).

- University of Zurich

- Vercammen, James A., 1995, Credit bureau policy and sustainable reputation effects in credit markets, Economica 62, 461-478.

- CrossRef,

- Web of Science $®$ Times Cited: 15

- University of Zurich

- Von Thadden, Ernst-Ludwig, 1995, Long-term contracts, short-term investment, and monitoring, Review of Economic Studies 62, 557-575.

- $\underline{\text { CrossRef }}$

- University of Zurich

- Von Thadden, Ernst-Ludwig, 2004, Asymmetric information, bank lending, and implicit contracts: The winner's curse, Finance Research Letters 1, 11-23.

- CrossRef

- University of Zurich

- Yosha, Oved, 1995, Information disclosure costs and the choice of financing source, Journal of Financial Intermediation 4, 3-20.

- CrossRef,

- Web of Science® Times Cited: 76 
- University of Zurich 